\title{
Developing Information and Communication Technology - Based Learning Materials for Teaching English at University Level in a Distance Learning Context
}

\author{
Sunu Dwi Antoro \\ English Education Program, \\ Universitas Terbuka \\ Tangerang Selatan, Indonesia \\ sunudw@yahoo.com
}

\begin{abstract}
The integration of Information and Communication Technologies (ICTs) in education has enhanced the power of teaching and learning process. ICTs have been used to deliver learning material through many tools such as email, blogs, YouTube, wiki, discussion boards, and others online application. Education dominantly uses computer technology to encourage innovation in teaching such as Computer Assisted Instructional (CAI). Computers can also be used to provide distance education for facilitating online learning and interaction. They are given the chance to learn through computer-based instruction schemes. Some experts and practitioners of education in language teaching have created the Computer Assisted Language Learning (CALL) that strongly supports the utilization of ICT in language learning. This tool is flexible, rich and interactive in the term of time and place and in term of encouraging students in learning language at their own pace. This is due to the computer's ability to present learning materials which has more diverse ways than either a book or video does. In addition, it is able to generate online interaction and improve communicative competence, including providing authentic material to the distance language learning environment and for self-directed learning. This paper will discuss about how to utilize all of these ICTs' abilities as the basic facilities to create IT-based learning materials for supporting distance language teaching and learning.
\end{abstract}

Keywords-ICT for learning; distance English learning materials; self-directed learning; online interaction

\section{INTRODUCTION}

Distance learning system has been familiar in Indonesia since Universitas Terbuka was opened in 1984. The existence of distance education in Indonesia was reinforced by the government regulation of the Minister of Education and Culture of the Republic of Indonesia number 109 of 2013 about the implementation of distance learning in higher education [10]. In this regulation distance learning is as a means of teaching-learning process that is conducted in a long-distance through the use of various communications media. It is "an institution- based and a formal education where the learning group is separated, and where interactive telecommunication systems are used to connect learners, learning resources, and instructor"[12]. The definition of distance learning from UNESCO was stated that "an educational process and system in which all or a significant proportion of the teaching is carried out by someone or something removed in space and time from the learner" [3].

The main concept of distance learning is a learning process which separates learners and teacher in different time and place [12] using various media for learning interaction. Media function to facilitate teaching and learning process that can replace the role of teacher as that in the conventional face-toface mode. The first media used was correspondence study using the post medium [12], [3]. The interaction between learners and teacher used written learning material sent via post. The next media of distance language learning was facilitated by instructional learning materials called modules which are designed for self-directed learning so that students can learn well [1].The medium of interaction changes gradually in line with the advances of ICT which provides more flexible distance learning process through available technological tools and application such as e-mail, blogs, wiki, Skype, mobile devices [2].

Students in a distance learning system are required to learn independently and efficiently. To learn in a distance learning system needs self-directed learning ability by the doing speed reading and understanding contents of learning materials. Self-directed learning needs independent learning, selfdiscipline, initiative learning, and a strong motivation for the students to learn. Students are also required to manage time efficiently, learn regularly based learning self-determined schedule.

Teaching English in distance context needs learning materials as the main learning resources for learning process [5] to facilitate distance language learning. Printed learning materials are the original media to cover the content materials and cover the characteristic of flexible learning material not just learning the language but use English for communication 
as well. It should meet the "effective self-learning" [14]. Another characteristic of distance learning material is "selfinstructional material" [4] material that provides students learn the material as if they are instructed by the teachers. The characteristics self-instructional learning materials are reflective learning materials indicated by some frequent questions, learning activities, exercises, formative evaluation and feedback [4]. The instruction language learning material should be written to cover the need of self-directed learning.

Now days the instructional media for teaching English in a distance learning system get the benefit from the era of Information and Technology (IT). Distance English language learning is possible to use IT both for supporting media of learning materials and learning process modes. To create learning material using IT there are three types of English language teaching material, namely blended learning materials, web-based learning materials, and multimedia learning materials.

\section{BLENDED LEARNING MATERIALS}

Blended learning materials are printed learning materials which are integrated with technology-based learning materials. These learning materials are designed into two parts, one is basically printed-based learning materials and another part is the materials which are completed with media technology to make them easier for the students to learn. For example, the course of speaking is integrated with video; Listening course is integrated with audio. It is called blended learning material because it is integrated with IT in the form of online learning. Blended learning materials are written into two steps, first develop printed learning materials, and then develop technology-based learning materials which is called "non printed material'"[5].

\section{A. Printed Learning Materials}

Printed learning materials for distance language learning are the main learning media in the distance language learning process. It is the first learning media since the correspondence mode of distance learning system [3]. It is designed to facilitate teaching and learning English in distance context. The instructor-created print media namely the "courses syllabus and the interactive study guide" [12] and it is completed with additional illustration such as pictures, tables, figures, and graphics to make easier learning the content.

There are three parts of printed learning materials that should be developed include the introduction, presentation of materials and closing activities. The components of source of learning material consist of examples, explanatory text, learning activities with feedback, diagrams and illustrations, topic summaries [13]. The introduction contains a brief description of the course contents, its relevance, benefits course goals, and instructional objectives. The course goal describes the competence of the course and topics presented and it is categorized into the general and specific instructional objectives, introductory section components [5].

The presentation of learning materials is in the form of learning material descriptions formulated using communicative presentations as if teaching using face-to-face mode. The presentation can be explaining materials, giving examples, practicing language skills, discussing topics, giving exercises / assignments. The content of the course comprising topics and subtopics, and exercises" [5]. The last part of printed learning materials is the closing activities consisting of summary, formative assessment and feedback, list of references, and glossary of terms" [5]. The summery is written to tells the students the essential learning materials that are already discussed in one unit lesson. Formative assessment is given to every topics to measure the students' learning progress equipped with feedback to facilitate learners to check their learning achievement for one unit learning.

\section{B. Technology-based Learning Materials}

The second step for developing blended learning material is developing technology-based learning material in the form of video, audio, and online platform. These kinds of learning materials are integrated into the printed-based learning materials. Video is developed by writing learning materials in the form of rundown video scripts. The scripts contain players, script of speech, location and description of action for the players and then produced into a video learning materials. For developing the audio is almost the same with developing video for distance learning. In audio there isn't any description of setting. The materials of the script are taken from the printed material. Another technology-based learning material is the online learning material used in online tutorial. The online learning material is written based on the printed-based learning material to initiate students learn.

\section{WEB-BASED LEARNING MATERIALS}

Web-based English teaching materials for distance learning are English language teaching materials prepared, executed, used, and presented with web media. Web-based materials for distance English teaching are also referred to an internet-based English language teaching materials or online teaching materials. It is written for supplementing modules to enrich its content materials.

The materials are generally text materials presented through internet network system facilitated with hyperlinks. The text materials are also completed with drills and exercises, for example in writing learning materials, there are some exercises to enhance writing skills competence. The hyperlinks allow students to access materials and link to another material without any physical and geographical restrictions, as long as the subject is available on the web. With the hyperlink facility the web-based learning materials become very rich sources of learning. Search engines can also help to find a subject that can be used as a link.

Web-based learning development procedures include formulating learning objectives, selecting topics, and preparing evaluation system and tools, collecting references, writing learning materials, editing, uploading, and reviewing in the case of materials, media, and accessibility. The first step is to determine the learning objectives clearly, to whom the target of the teaching materials for. Learning objectives indicate who they are, what skills they should master, and in which the position of learning materials that will be presented 
in the curriculum. Similarly, in the preparation of web-based learning materials should indicate targets such as learning objectives, topics, subtopics, presentation strategies, and references. These indicators are put into the blue print of media program as guide for developing the text of the material.

Table 1. Blueprint of Media Program

\begin{tabular}{|c|c|c|c|c|c|}
\hline \multicolumn{3}{|c|}{$\begin{array}{ll}\text { Subjects } & : \ldots . \\
\text { Topic } & : \ldots \\
\text { Objectives: } . \ldots\end{array}$} & \multicolumn{3}{|c|}{$\begin{array}{l}\text { Writer of Web text : .... } \\
\text { Content Reviewer : ... } \\
\text { Media Reviewer } \quad: . .\end{array}$} \\
\hline No & $\begin{array}{l}\text { Learning } \\
\text { Objectiv- } \\
\text { es } \\
\end{array}$ & Topics & Sub Topics & $\begin{array}{l}\text { Presentat- } \\
\text { ion } \\
\text { Srategies }\end{array}$ & $\begin{array}{l}\text { Referen- } \\
\text { ces }\end{array}$ \\
\hline 1. & $\begin{array}{l}\text { The } \\
\text { students } \\
\text { are able } \\
\text { to ..... }\end{array}$ & $\begin{array}{l}\text { Word } \\
\text { meanings }\end{array}$ & $\begin{array}{l}\text { - Reference } \\
\text { - Lexical } \\
\text { relations \& } \\
\text { derivative } \\
\text { relations }\end{array}$ & $\begin{array}{l}\text { Texts/ } \\
\text { Images } \\
\text { /photos } \\
\text { audio }\end{array}$ & $\begin{array}{l}\text { Saeed.J.I. } \\
\text { Semantics } \\
\text {.Oxford: } \\
1997 .\end{array}$ \\
\hline 2. & $\begin{array}{l}\text { The } \\
\text { students } \\
\text { are able } \\
\text { to .... }\end{array}$ & $\begin{array}{l}\text { Sentence } \\
\text { Relations } \\
\text { and } \\
\text { Truth }\end{array}$ & $\begin{array}{l}\text { - Logic and } \\
\text { truth } \\
\text { - Types of } \\
\text { truth }\end{array}$ & $\begin{array}{l}\text { Texts } \\
\text { /images/ } \\
\text { Photos } \\
\text { /audio }\end{array}$ & $\begin{array}{l}\text { Saeed.J.I. } \\
\text { Semantics } \\
\text {.Oxford: } \\
1997 .\end{array}$ \\
\hline
\end{tabular}

The blue print of web-based learning material provides guidance and reference in developing script web language learning materials. It will help the writer to determine the contents as well as considering the level of material difficulty, the importance of learning material, the usefulness, renewal of the materials, and anything that has not been known, or discussion of other viewpoints. The second step is to determine how the materials are presented through web. In the third step the selected materials are put into materials mapping.

After the script of learning material is completed, then continue to determine the way of presentation into web. Presenting web-based learning materials can be linear and not linear. To guide the production, the learning material script writer designs the flow chart to guide the producer to present learning materials in web. It is usually put into chart as seen the following flow chart modified from [7].

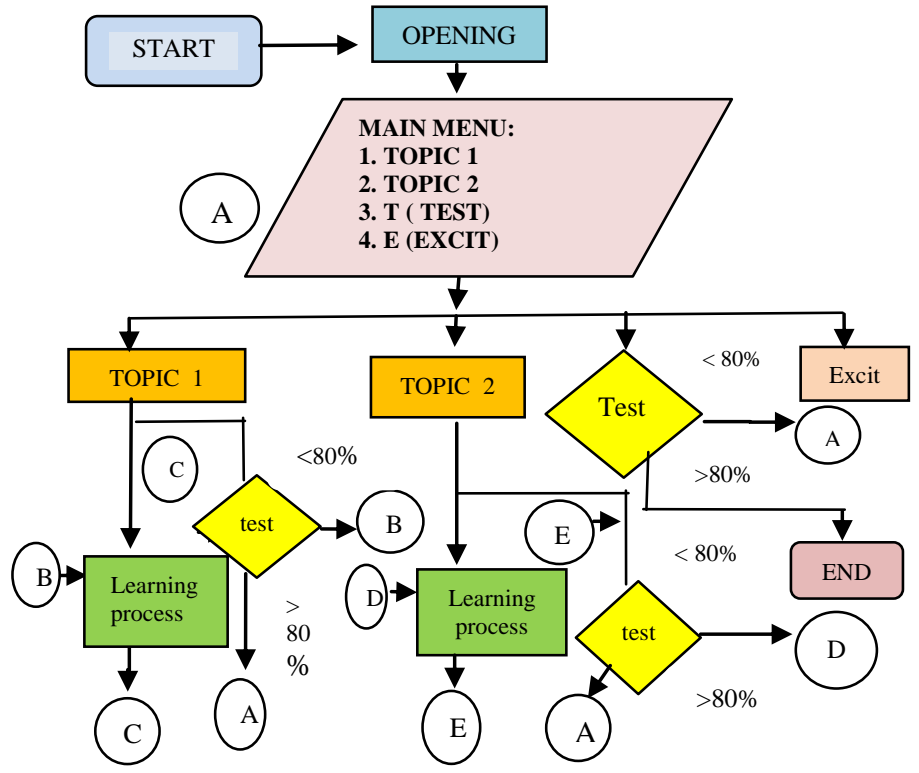

Fig.1. Example of flow chart of web materials
By using a flow chart of a learning material developers can set the order of presentation of the material weather it is linear or non-linear. It is set into linear if the material has content gradations to reflect the prerequisite requirements for the students to learn sequentially. If it doesn't require prerequisite learning material, it should be presented in not linear way; the students can learn learning materials at random. When it has both prerequisite and non prerequisite requirements the presentation of learning materials can be the combination of linear and non-linear way. The following pictures is the example of web-based learning material.

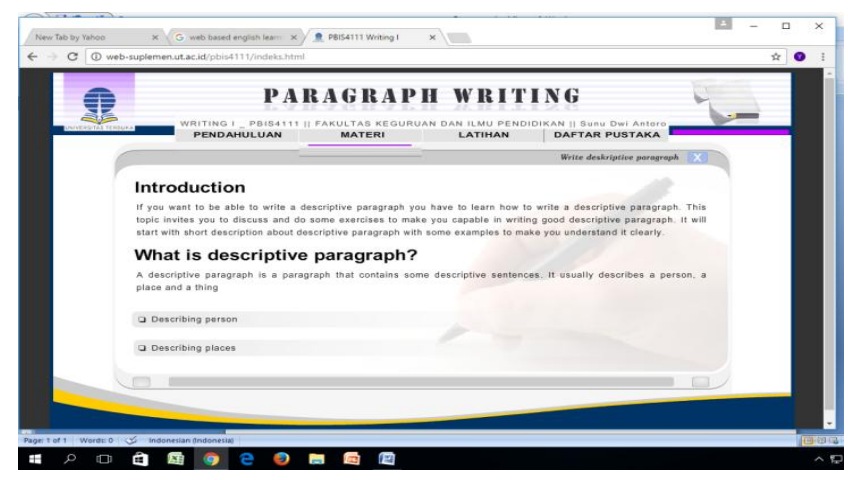

Fig. 2. Example of web-based learning material application

This pictures shows the tittle of topic, and menus of navigation introduction, materials, exercises, references. In the material navigation comprises of sub topics completed with the description.

\section{Multimedia LEARNing Materials}

Multimedia technologies provide distance institutions to deliver learning system not only through printed materials but also use multimedia learning materials as well. Multimedia is applications that use multiple media to their advantages including text, images, drawing (graphics), animation, video, sound (including speech), and most likely interaction of somekind"[9]. It is also defined as "the combination of text, pictures, audio, and video on a single platform"[11] to make more flexible delivery in the distance learning system.

By using multimedia technology, teaching English through distance learning system enables to design, store, assess, and distribute multimedia language learning material in the form of digital [8]. Distance English language learning material seems to be more interactive rather than just printed-based language learning material. This situation causes the concepts of developing the non-printed material based on the digital media.

Multimedia can support English language learning material that combines multiple types of media with multimedia assets. Assets are text, images, audio, slide show, animation, video, and interactivity [8] to transfer English learning materials to learn easily. The combination of multimedia assets and learning materials will create the interactive learning process and learning assessment as well. The interactivity in the assessment process is formulated from 
digital assessments that provide students to check learning progress, and give automatic feedback. Digital contents for assessment can be in the form of true false facility, drop down, fill in the blank, and multiple choices [8].

There are six steps of developing digital learning materials. First, the writer select essential material which needed more explanation from modules, then write learning material based on other references. Second step is to determine the topic, formulate the instructional objectives, break down the instructional objectives into sub topics, write the summaries, decide which material to present into text, which one with images, slide show, animation and video, etc. The third step is to change the long text into slide show, change images into animation or interactivity. At the fourth step writer changes assessment into interactivity. Dialogues can be presented with video. For inserting future change it can be used pop up window. In the fifth step, distribute the material into: text, image, slide show, animation, video, interactivity and assessment. Finally the last step is developing the content structure: number, name of assets, asset category, and kind of assets [8]. These processes still continue to the development of the storyboard.

After distributing the materials into text, image, slide show, animation, video, interactivity and assessment, then the next step is developing storyboard as the basic of production. Storyboards are "visual presentations that describe screen by screen what will happen in the final e-lesson"[6]. It is constructed by developing content structures, choosing the layout of each page, gathering the assets for references, writing the asset description for every asset in each page, combining the content structures, determining the layout, and describing assets into storyboard document[8].Structure content is developed using the asset that will be used and the content of the program. Write the name of asset; decide what category that will be used to show the assets and the topic of each asset. Asset description contains the narration about the topic lesson related with digital assets that will be used to present the materials [8].. The form of presentation can be slide show narration slide show photo, slide show text box.

Table 2. Example of Storyboard

\begin{tabular}{|c|c|}
\hline $\begin{array}{ll}\text { SCREEN DISPLAY } \\
>\quad \text { A Paragraph Structure } \\
>\quad \text { A Topic Sentence } \\
>\quad \begin{array}{l}\text { How to start writing } \\
\text { paragraph }\end{array}\end{array}$ & $\begin{array}{l}\text { NARRATION } \\
\text { To be able to write a paragraph, } \\
\text { one should understand the } \\
\text { O Paragraph Structure } \\
\text { O Unity and Coherence } \\
\circ \text { Topic Sentence } \\
\text { How to start writing } \\
\text { paragraph }\end{array}$ \\
\hline $\begin{array}{l}\text { DESCRIPTION OF SCREEN } \\
\text { - First came the main menu } \\
\text { paragraph structure, topic } \\
\text { sentence, unity and coherence, } \\
\text { how to start writing a paragraph } \\
\text { - When the narrator explain the } \\
\text { meaning of paragraph structure } \\
\text { then writing the paragraph } \\
\text { structure flickering } \\
\text { - When the narrator describes the } \\
\text { theory of unity and coherence, the } \\
\text { unity and coherence posts. Etc... }\end{array}$ & $\begin{array}{l}\text { DESCRIPTION OF } \\
\text { ANIMATION/ VIDEO/ } \\
\text { AUDIO }\end{array}$ \\
\hline
\end{tabular}

This storyboard still needs to be reviewed by content expert and media expert to fit the validity and reliability of content and media of instruction. The final step after storyboards are completed then they will be used by web developer to create the interactive e-lesson [6].

\section{CONCLUSION}

Teaching English through distance learning system was in fact difficult to realize since teaching of language skills need a lot of practices. At the correspondence era of distance learning mode, distance English language was supported with printedbased learning materials. The printed-based learning materials were combined with self-regulated learning guides to provide learning interaction. The development of English language learning material moves from correspondence learning materials to text books which is designed for self-directed language learning called modules. Instructional learning material was design to provide learners to learn learning materials by themselves, explain to them, facilitate flexible learning, give complete material, and offer interactive learning. Text-based learning materials then are benefited with the advances of information and technology and it come to blended learning material. Text-based learning material is no longer the primary delivery system of English distance learning, digital learning material such as multimedia learning material and web- based learning material adds the convenience and flexibility learning both in terms of the attractiveness of material and interaction in distance learning. Medium of interactions are also provided by IT like e-mail, Skype, mobile learning with smart phone and tablet, blogs etc. All of the advances of IT are able to cover the impossible learning language skills to the possible and flexible learning language skills.

\section{REFERENCES}

[1] A. Suparman, "Desain instruksional modern". Jakarta: Penerbit Erlangga, 2012.

[2] ] E. Amiri, "A study of the application of digital technologies in teaching and learning english language and literature". International Journal of Scientific \& Technology Research, vol. 1, Issue 5, June 2012.

[3] M. Burns, M. Distance education for teacher training: modes, models, and methods.

[4] Bharathi, Selft-directed learning and learner autonomy in English language teacher education: emerging trends. ELT Voices-India. International Journal for Teachers of English, Volume 4, Issue 1. 2321-7170. 2014.

[5] D. Mutiara, A. Zuhairi \& S.Kurniati, "Designing, developing, producing and assuring the quality of multi-media learning materials for distance learners: lessons learnt from indonesia's universitas terbuka", Turkish Online Journal of Distance Education-TOJDE, ISSN 1302-6488, Volume: 8 Number: 2 Article: 8, April 2007

[6] B. Ghirardini, "E-learning methodologies a guide for designing and developing e-learning courses". FAO. 2011

[7] H. Gunarto.. "Telaah teknologi online untuk kebutuhan bahasa. Bahan presentasi dalam pelatihan penulisan naskah online. 2006. 
[8] Kandel Multimedia. "Pelatihan pengembangan drylab. PT Kandel Divisi Multimedia".Jakarta: 2010

[9] Z. Nianli, \& M.S. Drew, Fundamental of multimedia. Person Educational International.2004

[10] Peraturan Menteri Pendidikan dan Kebudayaan Nomor 109 Tahun 2013 Tentang Penyelenggaraan Pendidikan Jarak Jauh Pada Pendidikan Tinggi available at http://sindikker.dikti.go.id/dok/permendikbud/permen_tahun201 3 nomor109.pdf

[11] S. Rajaram,"Effective use of web-based resources for enhancing esl learning Environment". Greener Journal of Educational Research Vol. 1 (1), pp. 015-018. 2011
[12] M. Simonson, S. Smaldino, M. Albright, \& S.Zvacek, Teaching and Learning at a Distance: Foundations of Distance Education. 5th ed. Boston: Pearson.2012

[13] _ COL. Creating learning materials for open and distance learning. Vancouver: Commonwealth of Learning (COL). 2005

[14] Mohammad Habibur RAHMAN, "Developing Course Materials for Open and Distance Learning": BOU Perspective. Turkish Online Journal of Distance Education-TOJDE ISSN 1302-6488 Volume: 7 Number: 4 Article: 4, July 2006 